\title{
1 The origin and evolution of cell-intrinsic antibacterial defenses in eukaryotes
}

\author{
Daniel J. Richter ${ }^{a}$ and Tera C. Levin ${ }^{b}$
}

a. Institut de Biologia Evolutiva (CSIC-Universitat Pompeu Fabra), Barcelona, Catalonia, Spain

b. Division of Basic Sciences, Fred Hutchinson Cancer Research Center, Seattle, Washington, United States

Corresponding authors: Richter, Daniel J. (daniel.j.richter@gmail.com), Levin, Tera C. (tlevin@fredhutch.org)

Abstract (120 words limit)

To survive in a world dominated by bacteria, eukaryotes have evolved numerous self-defense strategies. While some defenses are recent evolutionary innovations, others are ancient, with roots early in eukaryotic history. With a focus on antibacterial immunity, we highlight the evolution of pattern recognition receptors that detect bacteria, where diverse functional classes have been formed from the repeated use and reuse of a small set of protein domains. Next, we discuss core microbicidal strategies shared across eukaryotes, and how these systems may have been co-opted from ancient cellular mechanisms. We propose that studying antibacterial responses across diverse eukaryotes can reveal novel modes of defense, while highlighting the critical innovations that occurred early in the evolution of our own immune systems.

Short title (50 characters limit): Evolution of antibacterial defenses in eukaryotes

Keywords (1-5): evolution; eukaryotes; antibacterial defense; innate immunity

\section{The unexplored diversity of eukaryotic antibacterial defenses}

Since their origin via endosymbiosis more than a billion years ago, eukaryotes have lived in a world dominated by bacteria $(1,2)$. The perpetual struggle to avoid exploitation by bacterial pathogens has shaped molecular strategies for microbial recognition and response across eukaryotic history. Here, we review some of the most ancient cell-intrinsic antibacterial defenses in eukaryotes, which we argue formed the foundation of innate immune systems in groups such as plants and animals $(3,4)$. A more thorough exploration of antibacterial strategies across eukaryotes can illuminate the ancestry of immunity and lead to the discovery of new pathways and mechanisms of antibacterial defense.

Plants, animals, fungi and other highly-studied macroscopic groups represent only a fraction of eukaryotic diversity (Figure 1) (5), while some other eukaryotic lineages have been so little studied that the majority of their species are known through environmental sequencing alone. The disparities between the diversity of studied species and the actual scope of eukaryotic diversity are evident in the biased phylogenetic distribution of formally described genera relative to a sequence-based survey of operational taxonomic units from a global-scale marine dataset (OTUs, a unit of sequence diversity roughly equivalent to genera; Figure 1). This environmental survey from Tara Oceans, the largest environmental sequencing project to date, provides what is currently our best window into eukaryotic diversity in the ocean (6). Nevertheless, the Tara Oceans dataset is an underestimate of global eukaryotic diversity, as other environments, such as soil, may harbor even higher diversity (7). As shown in Figure 1, most 
eukaryotic groups have received little, if any, experimental characterization of antibacterial defenses, so analyses of such defenses currently rely on bioinformatic predictions. Yet even these approaches are limited, as genome-scale data are only available for a small subset of these groups. Specifically, lineages such as Dinophyceae, core syndiniales, Radiolaria and Diplonemea contain comparatively few taxa with formal morphological descriptions or sequenced genomes, yet harbor an enormous diversity waiting to be explored.

In this review, we integrate current research on eukaryotic antibacterial defense systems, together with Pfam protein domain queries of MMETSP data (a large-scale project that sequenced the transcriptomes of several hundred diverse species of marine microbial eukaryotes (8)), to describe cell-intrinsic bacterial recognition and killing mechanisms that are most broadly conserved across eukaryotes. For brevity, we focus on bacteria-proximal steps, rather than intermediates in immune signaling cascades. We consider the following pathogens and mechanisms outside of our scope: (i) gene families restricted to a single eukaryotic lineage (e.g., animal-specific RIG-I-like receptors (9)) (ii) mechanisms that target viruses and selfish elements, including RNAi (10) (see also a review by Zhao and Guo in this issue (11)), (iii) eavesdropping and response to chemical signals produced by bacteria $(12,13)$, and (iv) parasitism of eukaryotes by other eukaryotes (e.g. $(14,15))$. Instead, we present core antibacterial strategies that are shared across eukaryotes, highlighting those that are deeply conserved and those that have experienced recurrent innovation involving a limited number of functional protein domains. We also propose paths forward to discover unknown defenses in little-studied eukaryotic lineages.

\section{Convergence and conservation in bacterial pattern recognition proteins}

A eukaryotic cell's first step in an antibacterial response is to recognize the telltale signs of bacteria, typically via pattern recognition proteins. The evolutionary histories of these proteins fall into two categories: some are found across diverse eukaryotic groups and were therefore likely present in the last eukaryotic common ancestor (LECA), and others evolved after the LECA, within one or more groups independently (Table 1). Among the many gene families in the first category are lectins, a broad class of proteins that has been associated with sugar-based bacterial recognition in multiple eukaryotic groups (16-18). More recently evolved gene families include the cytosolic DNA/cyclic dinucleotide sensors cGAS and STING, which appear to have arisen in eukaryotes only once, in Choanozoa (animals and their closest relatives, Choanoflagellatea) (19) (although cGAS-like proteins exist in bacteria (20)). Here, we focus on the evolutionary histories of three classes of proteins that mediate bacterial recognition and have been well studied in animals and plants: TLRs (Toll-like receptors), RLKs (receptor-like kinases) and NLRs (nucleotide-binding domain, leucine-rich repeat superfamily proteins) (21-23) (Figure 2). These classes can be identified by unique combinations of protein domains, each of which are associated with known functions. Leucine rich repeat (LRR) domains, which are common to all three classes, can recognize molecules produced either by bacteria or by the eukaryotic cell in response to a bacterial attack. Animal TLRs, which sense extracellular bacterial molecules or those within intracellular vacuoles, pair signal recognition via LRR domains with cytoplasmic TIR domains, which transmit the signal inside the cell. RLKs studied in plants pair perception by extracellular LRRs (or a lysin motif, LysM) with intracellular kinase domains (24). NLRs are cytoplasmic recognition proteins that are thought to have evolved convergently in both plants and animals, where they participate in distinct antibacterial defense pathways (25). NLRs commonly found in animals pair NACHT domains with LRRs, while those of plants encode NB-ARC and LRR domains.

Outside of animals and plants, a survey of eukaryotic diversity indicates a surprising number of eukaryotic lineages have proteins with both canonical and novel combinations of LRR, TIR, NACHT and NB-ARC domains (Figure 2). Canonical TLR domain architecture appears to be restricted to Choanozoa 
(26). In striking contrast, RLK-like domain architectures are extremely broadly distributed (27), found across every eukaryotic lineage except Apicomplexa. NLR domain pairs (NACHT/LRR and NB-ARC/LRR) are present in multiple evolutionarily distant lineages, although several of the well-studied and functionally characterized NLRs in animals and plants (NOD, NLRP and RPS) (28) appear to be lineage-specific elaborations of ancient and widespread NACHT/LRR or NB-ARC/LRR proteins $(23,25)$ (Figure 2).

Beyond these canonical domain architectures, other eukaryotes have shuffled the domains in their pattern recognition proteins into novel combinations that hint at divergent modes of antibacterial signaling, potentially via more direct routes. For example, animal TLRs initiate downstream kinase signaling cascades via interaction of their TIR domains with intracellular adapter proteins (29). In Choanoflagellatea, there is a TLR-like protein (known as a 'kinase TLR') that contains its own intracellular kinase domain, which may directly initiate a signaling cascade (26) analogous to plant RLKs, which pair extracellular LRR or LysM sensing domains with intracellular kinases (24).

In a parallel example, some animal NLRs include a protein domain (CARD or PYRIN) that functions to recruit caspase proteases, which cleave downstream substrates, generally in the context of programmed cell death (30). Two independently-evolved NLR-like proteins in Diatomeae and in Haptista directly link LRR/NACHT or LRR/NB-ARC domains to a CHAT domain, a caspase-related peptidase domain that may directly perform caspase-like functions (Figure 2). These intriguing cases remain to be experimentally characterized, but may provide important clues as to how immune signaling cascades have been wired and rewired over evolutionary time.

There is also experimental evidence for bacterial recognition and response in lineages with unusual combinations of TLR-like or NLR-like domains. In Dictyostelium (Amoebozoa), response to bacterial lipopolysaccharide depends on a protein that combines a TIR-domain with RCC1 and Ankyrin repeat domains (31). Fungi (Nucletmycea) encode a diversity of NLR-like proteins (32) where NACHT and NB$A R C$ domains are linked to a variety of enzymatic and protein-protein interaction domains, but while fungi have been shown to produce antibacterial compounds in response to bacteria (33), a role for fungal NLRs in this recognition has not been identified. In Choanoflagellatea, there is an NLR-like protein that links LRR and NACHT domains with phospholipase functional domains (PI-PLC-X/PI-PLC-Y). In all of these cases, immune signaling domains have been organized into new contexts relative to well-studied proteins in animals and plants. These examples of evolution by domain shuffling are particularly intriguing, because they may link bacterial sensing to novel downstream signaling cascades.

Given these observations, how might pattern recognition proteins have originated in eukaryotes? Although canonical pattern recognition domain combinations are found in relatively restricted sets of eukaryotic lineages, their core constituent domains (LRR, TIR, Pkinase, NB-ARC, NACHT) were each present in the LECA. This suggests either that TLR-, RLK- and NLR-like domain architectures evolved independently in multiple lineages via domain shuffling, or that these proteins were present in the LECA and subsequently lost numerous times independently. Alternatively, they may have experienced more complex scenarios involving a history of horizontal gene transfer and repeated gene loss. Distinguishing among these alternative scenarios should be possible with increased species sampling and detailed phylogenetic analyses. Overall, these examples illustrate how a relatively small set of individual protein domains appear to have been used and reused as functional building blocks in the evolution of diverse pattern recognition proteins across eukaryotes.

\section{Ancient mechanisms of cell-intrinsic, microbicidal control}


Once recognized by the cell, eukaryotes deploy a number of cellular and molecular strategies to kill bacteria. Some conserved mechanisms of cell homeostasis that were present in the LECA can be redeployed to eliminate bacteria (Table 1). However, because the proteins involved may retain their homeostatic roles, predicting whether a given eukaryote uses these proteins for pathogen defense is often not possible based on sequence analysis alone, and instead requires experimental validation. Nevertheless, we present modes of bacterial killing that appear to be most broadly conserved across eukaryotes.

Eukaryotic species with robust cell walls primarily interact with bacteria extracellularly (34), whereas species with more permeable barriers and/or those that uptake bacteria as food require both intracellular and extracellular killing mechanisms. Intracellular bacteria can be targeted using cellular machinery involved in the degradation and recycling of macromolecules. For example, autophagy, which likely dates back to the LECA (35), allows eukaryotic cells to break down organelles or cytoplasmic contents during periods of cellular damage and stress (36). Autophagy can also encapsulate and eliminate intracellular bacteria, both those residing within host vacuoles and those that have escaped into the cytosol (Figure 3). This process, referred to as "xenophagy", has been shown to fight bacterial infections within the cells of animals (37) and Amoebozoa (38). Eukaryotes also deploy a number of strategies to restrict microbial growth within the cell. Bacteria internalized via phagocytosis or other uptake pathways are typically sequestered within lysosomes and/or digestive vacuoles (Figure 3) (39). Here, multiple antibacterial strategies are simultaneously deployed to transform vacuoles into toxic, nutrient-poor microenvironments. These strategies include compartment acidification, the generation of reactive oxygen species (ROSs), the activity of proteases, nucleases, and other enzymes to break down macromolecules, and the use of vacuolar transporters to remove nutrients such as iron that could potentially support microbial growth (40). This compartmentalization allows eukaryotes to efficiently kill intracellular bacteria while minimizing harm to the host cell. A broad diversity of eukaryotes create lysosome- and autophagosome-like vacuoles for recycling cellular material, which can also be used to recover nutrients from killed bacteria (35). Therefore, the production of these toxic vacuoles is likely an ancient antimicrobial strategy for targeting intracellular bacteria.

Eukaryotes can target extracellular bacteria by secreting antibacterial molecules. While this is a common strategy, the molecules themselves can be highly variable in terms of their molecular structures, mode of action, and evolutionary histories. For example, lysozymes, which break down the peptidoglycan cell walls of bacteria, are a highly diverse family of proteins that are broadly distributed, likely present in the LECA (41). Other secreted defenses include diverse antimicrobial peptides (42), iron-scavenging proteins $(43,44)$ and small molecule antibiotics $(13,45)$, which tend to evolve so rapidly that they can be difficult to identify from sequence alone in the absence of functional data. In contrast, some generically toxic molecules, such as ROSs, are produced by many types of eukaryotes and may be released either at the plasma membrane $(46,47)$ or via organelles such as mitochondria or chloroplasts $(48,49)$.

If these intracellular and extracellular antimicrobial strategies are inadequate to control pathogens, eukaryotes can also take drastic measures and undergo programmed cell death (50). Explosive, lytic modes of cell death can release toxic molecules to kill bacteria while alerting neighboring cells to the presence of pathogens (51). Apoptotic cell death can serve to kill intracellular pathogens and trap them within dying host cells. Although programmed cell death might initially seem to be counter-productive to unicellular organisms, apoptotic-like death has been observed across nearly all major eukaryotic lineages, including unicellular taxa (52). Particularly for those species that live in dense populations of cells, programmed cell death may be useful as an altruistic strategy to prevent pathogens from spreading through the population, akin to abortive infection mechanisms that bacteria use to combat bacteriophage (53). All together, the antibacterial immune strategies found in modern-day organisms are an evolutionary 
patchwork, with recently-evolved immune mechanisms built upon these widespread, ancient modes of defense.

\section{Finding missing modes of eukaryotic defense}

These are some of the cell-intrinsic antibacterial defenses that are the most ancient and broadly distributed across eukaryotic taxa (Table 1), but there is reason to believe that there are many more waiting to be discovered. One reason is that pathogen-interacting genes tend to be some of the fastest evolving genes in host genomes $(54,55)$, due to the strong selective pressures involved in evading pathogen infections (56). This rapid evolution raises challenges for studying the deep ancestry of defense pathways. Many eukaryotic lineages have been studied almost exclusively through sequence data, where probable gene functions are assigned based on conservation to experimentally characterized genes and genomes (largely from animals, plants, or fungi) (57). If cell-intrinsic defense proteins across eukaryotes evolve as rapidly as they do in animals and plants, defense genes are likely to be particularly difficult to identify in diverse, poorly-sampled eukaryotic taxa based on sequence alone. In addition, even within eukaryotic proteins where some conserved domains have been detected (e.g., TIRs and LRRs), additional, as yet uncharacterized, functional domains may lurk in their sequences if these domains are not prevalent in animals, plants, or fungi. In short: beyond the few, extremely conserved strategies (Figure $3)$, there are almost certainly a lot of defenses that we're missing!

What approaches can be used to discover unknown antibacterial defenses in diverse eukaryotes? An effective strategy would be to expand our experimental approaches to new and emerging eukaryotic model systems. Although the vast majority of microbial eukaryotes are not currently in culture, there are hundreds of cultured species (see Box 2 of (58)), many of which have yet to be probed for their responses to bacteria or bacteria-derived molecules (59). Bioinformatics-based approaches could begin by searching for proteins containing domains known to be associated with immune functions in other organisms, as in the examples of pattern recognition receptors we presented above. Once identified, the expression dynamics of these genes could be probed in response to bacterial exposure. For the expanding list of microbial eukaryotes whose gene expression can be manipulated (60), candidate gene immune functions could be further dissected using overexpression or knockout approaches.

The search for undiscovered antimicrobial functions without homology to known proteins will require a different approach. Because many genes for antimicrobial defense are differentially regulated upon bacterial exposure, genome-wide expression profiling in the presence and absence of bacteria (or bacterial products such as LPS or peptidoglycan) could generate candidate defense genes. Unbiased genetic screens could also be a powerful tool to identify antibacterial genes in those eukaryotes that lack genetic manipulation techniques. For example, for species with small, haploid genomes, random mutagenesis followed by whole-genome sequencing could identify genetic mutations that alter bacterial responses (as in (61)).

These approaches can be useful to understand eukaryotic responses to bacteria, yet eukaryotes must also discriminate among different bacterial species to tailor their antimicrobial responses appropriately. This raises the question: which bacteria should be used to elicit eukaryotic defenses? We propose two possible solutions. First, eukaryotes could be exposed to pathogens with exceptionally broad host ranges such as Legionella, which have been used in the lab to infect diverse eukaryotes including Metazoa, Amoebozoa, Ciliophora, and Heterolobosea (62). Alternatively, because eukaryotes are most likely to have adapted to the bacteria they encounter in their local environment, researchers may take advantage of the fact that many microeukaryotes are co-isolated and co-cultured with a community of bacteria. The composition of these microbial communities could be manipulated through nutrient restriction and/or 
antibiotic treatments to alter bacterial exposure. Eukaryotes could then be monitored for responses such as the induction of cell death, secretion of antimicrobials, or the production of autophagosome-like membranes. If bacteria in these communities can trigger eukaryotic antibacterial defenses, they could form a natural system to dissect host-pathogen interactions in the lab.

Why is it so important to study this under-sampled diversity of eukaryotic antibacterial defenses? First, we know that bacterial interactions are broadly important to the ecology, physiology, and even the endosymbiotic origin of eukaryotes $(1,2,13,15,63)$, but in most lineages the mechanisms shaping microbial interactions are unknown. Second, diverse eukaryotes can tell us about the origins and evolution of antibacterial defenses. Our eukaryotic ancestors lived with bacteria for hundreds of millions of years before the evolution of animals or plants, and their pre-existing strategies for managing bacterial interactions formed the starting point from which modern-day innate immune systems evolved (4). Learning about this ancestry can help us to make sense of the variety of defensive strategies that we see today. Third, these lineages may serve as rich hunting grounds to discover novel, yet broadly conserved, aspects of cell-intrinsic immunity. Such mechanisms may be easier to discover in organisms without the complications of adaptive immunity or complex interactions among immune cell types. For example, studies of Dictyostelium amoebae were critical in uncovering mechanisms of phagocytosis (e.g. (64)). These organisms also encode guanylate-binding proteins (GBPs), a protein family has relatively recently been discovered to function in animal antibacterial defense (65). Because the Dictyostelium genome only encodes one GBP as opposed to the dozens in animals, studies in amoebae could avoid some of the complications of functionally characterizing these defenses.

Finally, even if the defense mechanisms we uncover in these eukaryotes are different from what we know in animals and plants, they may still reveal entirely novel biological solutions to the problem of antibacterial immunity. Such mechanisms are bound to inspire new strategies and interventions to combat pathogenic bacteria. They can also broaden our conceptions of how immunity can work, giving us a glimpse into the diverse evolutionary paths that can be followed by defense systems in different eukaryotic lineages.

\section{Conflict of interest statement}

The authors declare no conflict of interest.

\section{Acknowledgements}

We thank Roman Barbalat, Darian Doakes, Mary Fontana, Barbara Kunkel, Jeannette Tenthorey, Russell Vance and Arielle Woznica for their comments on the manuscript. We thank Cédric Berney and Michelle Leger for helpful discussions. We acknowledge an anonymous reviewer for comments that led to improvements on the review. DJR is supported by a postdoctoral fellowship from the Beatriu de Pinós programme of the Government of Catalonia's Secretariat for Universities and Research of the Ministry of Economy and Knowledge. TCL is supported by a Pathway to Independence Award from the National Institute of Allergy and Infectious Disease and the National Institutes of Health (K99 Al139344).

\section{Figures}

Figure 1. The spectrum of diversity among eukaryotes. Phylogenetic tree of eukaryotic diversity based on (5) and annotated to show where species descriptions, genome-scale sequencing and studies 
of antibacterial defense have been concentrated. Well-known multicellular groups include animals 
Table 1. Bacterial recognition and defense gene families in eukaryotes. Gene families or processes known to be involved in defensive response to bacteria that are shared among multiple eukaryotic groups (group names correspond to Figure 1; when names correspond to internal nodes, evidence is present in all groups descending from the node). Genomic evidence is based on searches for diagnostic protein domain architectures in MMETSP data (required to be present in at least 2 species within a lineage, after removal of low levels of inter-species cross-contamination, as in (75)), complemented by literature searches when diagnostic architectures are not available. Hypotheses on the evolution of each domain architecture are constrained by currently available data, and may change as sampling of eukaryotic diversity increases. *: NLR-like proteins have been identified in the genomes of Nucletmycea. ${ }^{* *}$ : (76) also

\begin{tabular}{|c|c|c|c|c|c|c|c|}
\hline $\begin{array}{l}\text { Process/Gene } \\
\text { Family }\end{array}$ & $\begin{array}{l}\text { Known } \\
\text { Antibacterial } \\
\text { Function(s) }\end{array}$ & $\begin{array}{l}\text { Experiment } \\
\text { al Evidence } \\
\text { in Group(s) }\end{array}$ & $\begin{array}{l}\text { Diagnostic } \\
\text { Protein } \\
\text { Domains (if } \\
\text { any) }\end{array}$ & $\begin{array}{l}\text { Genomic } \\
\text { Evidence in } \\
\text { Additional } \\
\text { Group(s) }\end{array}$ & $\begin{array}{l}\text { Likely } \\
\text { Evolved }\end{array}$ & $\begin{array}{l}\text { Non- } \\
\text { Immunity } \\
\text { Function(s) }\end{array}$ & Reference(s) \\
\hline $\begin{array}{l}\text { TLRs (Toll-like } \\
\text { receptors) }\end{array}$ & $\begin{array}{l}\text { Extracellular } \\
\text { pattern } \\
\text { recognition }\end{array}$ & Metazoa & $\begin{array}{l}\text { TLR, } \\
\text { transmembrane, } \\
\text { TIR }\end{array}$ & $\begin{array}{l}\text { Choanoflagellat } \\
\text { ea }\end{array}$ & $\begin{array}{l}\text { Once, in } \\
\text { Choanozoa }\end{array}$ & $\begin{array}{l}\text { Developmen } \\
\mathrm{t} \text { (Metazoa) }\end{array}$ & $(26,77,78)$ \\
\hline $\begin{array}{l}\text { Plant-type RLKs } \\
\text { (receptor-like } \\
\text { kinases, excluding } \\
\text { lectins) }\end{array}$ & $\begin{array}{l}\text { Extracellular } \\
\text { pattern } \\
\text { recognition }\end{array}$ & Streptophyta & $\begin{array}{l}\text { LRR, } \\
\text { transmembrane, } \\
\text { Pkinase }\end{array}$ & $\begin{array}{l}\text { All, except } \\
\text { Apicomplexa }\end{array}$ & $\begin{array}{l}\text { Present in } \\
\text { LECA and/or } \\
\text { independentl } \\
\text { y evolved in } \\
\text { multiple } \\
\text { groups }\end{array}$ & $\begin{array}{l}\text { Developmen } \\
\text { t, symbiosis } \\
\text { (Streptophyt } \\
\text { a) }\end{array}$ & $(27,79)$ \\
\hline $\begin{array}{l}\text { NLRs (nucleotide- } \\
\text { binding domain, } \\
\text { leucine-rich repeat } \\
\text { superfamily) }\end{array}$ & $\begin{array}{l}\text { Intracellular } \\
\text { pattern } \\
\text { recognition }\end{array}$ & $\begin{array}{l}\text { Metazoa, } \\
\text { Streptophyta }\end{array}$ & $\begin{array}{l}\text { NACHT or NB- } \\
\text { ARC, LRR }\end{array}$ & $\begin{array}{l}\text { Haptista, } \\
\text { Dinophyceae, } \\
\text { Diatomeae, } \\
\text { Nucletmycea* }\end{array}$ & $\begin{array}{l}\text { Independentl } \\
\text { y evolved in } \\
\text { multiple } \\
\text { groups }\end{array}$ & $\begin{array}{l}\text { Reproductio } \\
\text { n (Metazoa) }\end{array}$ & $(25,32,80)$ \\
\hline STING & $\begin{array}{l}\text { Cytosolic cyclic } \\
\text { dinucleotide } \\
\text { recognition }\end{array}$ & Metazoa & TMEM173 & $\begin{array}{l}\text { Choanoflagellat } \\
\text { ea }\end{array}$ & $\begin{array}{l}\text { Once, in } \\
\text { Choanozoa }\end{array}$ & - & (81) \\
\hline cGAS & $\begin{array}{l}\text { Cytosolic DNA } \\
\text { recognition }\end{array}$ & Metazoa & Mab-21 & $\begin{array}{l}\text { Choanoflagellat } \\
\text { ea }\end{array}$ & $\begin{array}{l}\text { Once, in } \\
\text { Choanozoa }\end{array}$ & - & (81) \\
\hline Lectins & $\begin{array}{l}\text { Microbial sugar } \\
\text { recognition and } \\
\text { agglutination or } \\
\text { recognition of } \\
\text { host danger } \\
\text { signals }\end{array}$ & $\begin{array}{l}\text { Amoebozoa, } \\
\text { Metazoa, } \\
\text { Streptophyta }\end{array}$ & \multicolumn{2}{|c|}{ Diverse and widely distributed } & $\begin{array}{l}\text { Present in } \\
\text { LECA and/or } \\
\text { independentl } \\
\text { y evolved in } \\
\text { multiple } \\
\text { groups }\end{array}$ & $\begin{array}{l}\text { Adhesion, } \\
\text { development } \\
\text {, symbiosis }\end{array}$ & $(17,82)$ \\
\hline $\begin{array}{l}\text { Guanylate-binding } \\
\text { proteins (GBPs) }\end{array}$ & $\begin{array}{l}\text { Target vacuolar } \\
\text { and cytosolic } \\
\text { bacteria for killing }\end{array}$ & Metazoa & GBP, GBP_C & $\begin{array}{l}\text { All, except } \\
\text { Rhodophyta, } \\
\text { Phaeophyceae, } \\
\text { Euglenozoa }\end{array}$ & $\begin{array}{l}\text { Present in } \\
\text { LECA }\end{array}$ & $\begin{array}{l}\text { Inhibits cell } \\
\text { proliferation, } \\
\text { migration }\end{array}$ & $(65,83)$ \\
\hline
\end{tabular}




\begin{tabular}{|c|c|c|c|c|c|c|c|}
\hline $\begin{array}{l}\text { Antimicrobial } \\
\text { peptides }\end{array}$ & $\begin{array}{l}\text { Disruption of } \\
\text { bacterial } \\
\text { membranes } \\
\text { and/or cell walls }\end{array}$ & $\begin{array}{l}\text { Amoebozoa, } \\
\text { Metazoa, } \\
\text { Nucletmycea } \\
\text { Streptophyta } \\
\text { ' } \\
\text { Rhodophyta, } \\
\text { Ciliophora, } \\
\text { Heterolobos } \\
\text { ea }\end{array}$ & \multicolumn{2}{|c|}{$\begin{array}{l}\text { Diverse and widely distributed } \\
\\
\\
\end{array}$} & $\begin{array}{l}\text { Present in } \\
\text { LECA and/or } \\
\text { independentl } \\
\text { y evolved in } \\
\text { multiple } \\
\text { groups }\end{array}$ & $\begin{array}{l}\text { Gut } \\
\text { homeostasis } \\
\text { (Metazoa), } \\
\text { rhizobial } \\
\text { symbiosis } \\
\text { (Streptophyt } \\
\text { a) }\end{array}$ & $(42,84)$ \\
\hline Lysozyme & $\begin{array}{l}\text { Disruption of } \\
\text { bacterial cell } \\
\text { walls }\end{array}$ & $\begin{array}{l}\text { Amoebozoa, } \\
\text { Metazoa, } \\
\text { Nucletmycea } \\
\text { Streptophyta }\end{array}$ & \multicolumn{2}{|c|}{ Diverse and widely distributed } & $\begin{array}{l}\text { Present in } \\
\text { LECA }\end{array}$ & - & $(41)$ \\
\hline $\begin{array}{l}\text { Nitric oxide } \\
\text { synthase (NOS) }\end{array}$ & $\begin{array}{l}\text { Production of NO } \\
\text { for bacterial } \\
\text { killing }\end{array}$ & Metazoa & $\begin{array}{l}\text { NO_synthase, } \\
\text { Flavodoxin, } \\
\text { FAD_binding, } \\
\text { NAD_binding }\end{array}$ & $\begin{array}{l}\text { Amorphea, } \\
\text { Chlorophyta, } \\
\text { Haptista, } \\
\text { Dinophyceae, } \\
\text { Cercozoa, } \\
\text { Diatomeae, } \\
\text { Chrysophyceae } \\
\text { Pelagophyceae } \\
\text {, Euglenida** }\end{array}$ & $\begin{array}{l}\text { Present in } \\
\text { LECA }\end{array}$ & $\begin{array}{l}\text { Intracellular } \\
\text { and } \\
\text { intercellular } \\
\text { signaling }\end{array}$ & $(76,85)$ \\
\hline $\begin{array}{l}\text { NADPH oxidases } \\
\text { (NOX, produce } \\
\text { reactive oxygen } \\
\text { species) }\end{array}$ & $\begin{array}{l}\text { Production of } \\
\text { superoxide for } \\
\text { bacterial killing }\end{array}$ & $\begin{array}{l}\text { Amoebozoa, } \\
\text { Metazoa, } \\
\text { Streptophyta } \\
\text { ' } \\
\text { Rhodophyta, } \\
\text { Phaeophyce } \\
\text { ae }\end{array}$ & $\begin{array}{l}\text { transmembrane( } \\
\text { s), } \\
\text { Ferric_reduct, } \\
\text { transmembrane( } \\
\text { s), } \\
\text { FAD_binding, } \\
\text { NAD_binding }\end{array}$ & $\begin{array}{l}\text { All, except } \\
\text { Apicomplexa, } \\
\text { Metamonada }\end{array}$ & $\begin{array}{l}\text { Present in } \\
\text { LECA }\end{array}$ & $\begin{array}{l}\text { Intracellular } \\
\text { and } \\
\text { intercellular } \\
\text { signaling }\end{array}$ & $(46,86-89)$ \\
\hline Nramp & $\begin{array}{l}\text { Removes metal } \\
\text { ions and acidifies } \\
\text { vacuoles }\end{array}$ & $\begin{array}{l}\text { Amoebozoa, } \\
\text { Metazoa, } \\
\text { Streptophyta }\end{array}$ & $\begin{array}{l}\text { Nramp, } \\
\text { transmembrane( } \\
\text { s) }\end{array}$ & $\begin{array}{l}\text { All, except } \\
\text { Metamonada }\end{array}$ & $\begin{array}{l}\text { Present in } \\
\text { LECA }\end{array}$ & $\begin{array}{l}\text { Metal ion } \\
\text { scavenging } \\
\text { for host } \\
\text { metabolism }\end{array}$ & (90) \\
\hline $\begin{array}{l}\text { Mitochondria and } \\
\text { chloroplast- } \\
\text { mediated defenses }\end{array}$ & $\begin{array}{l}\text { Production of } \\
\text { reactive oxygen } \\
\text { species }\end{array}$ & $\begin{array}{l}\text { Metazoa, } \\
\text { Streptophyta }\end{array}$ & Not available & - & $\begin{array}{l}\text { Present in } \\
\text { LECA }\end{array}$ & $\begin{array}{l}\text { Photosynthe } \\
\text { sis and } \\
\text { respiration }\end{array}$ & $(48,49)$ \\
\hline $\begin{array}{l}\text { Autophagy (incl. } \\
\text { xenophagy, etc.) }\end{array}$ & $\begin{array}{l}\text { Sequestering and } \\
\text { killing of } \\
\text { intracellular } \\
\text { bacteria }\end{array}$ & $\begin{array}{l}\text { Amoebozoa, } \\
\text { Metazoa, } \\
\text { Streptophyta } \\
\text { Kinetoplaste } \\
\text { a }\end{array}$ & $\begin{array}{l}\text { Numerous } \\
\text { genes and } \\
\text { pathways }\end{array}$ & $\begin{array}{l}\text { All, but lost in } \\
\text { species within } \\
\text { Nucletmycea, } \\
\text { Rhodophyta, } \\
\text { Metamonada }\end{array}$ & $\begin{array}{l}\text { Present in } \\
\text { LECA }\end{array}$ & $\begin{array}{l}\text { Disposal of } \\
\text { compromise } \\
\text { d cellular } \\
\text { material }\end{array}$ & (35) \\
\hline
\end{tabular}

\section{Papers of special interest:}

360 Special interest $\left({ }^{*}\right)$ or outstanding interest $\left({ }^{* *}\right)$

1. Reference 5. Adl SM, Bass D, Lane CE, Lukeš J, Schoch CL, Smirnov A, et al. Revisions to the Classification, Nomenclature, and Diversity of Eukaryotes. J Eukaryot Microbiol. 2019 Jan 1;66(1):4-119. 
* The most up to date taxonomy of eukaryotes, based on a consensus of phylogenetic studies. Includes information on the numbers of described genera in each group and their trophic characteristics.

2. Reference 15. Bjorbækmo MFM, Evenstad A, Røsæg LL, Krabberød AK, Logares R. The planktonic protist interactome: where do we stand after a century of research? bioRxiv. 2019 May $2 ; 587352$.

* A database gathering the results of roughly 500 publications describing roughly 2,500 inter-species interactions of planktonic protists (microbial eukaryotes), including those with bacteria. Categorizes interactions into three types (symbiosis, predation and parasitism).

3. Reference 17. Bellande K, Bono J-J, Savelli B, Jamet E, Canut H. Plant Lectins and Lectin Receptor-Like Kinases: How Do They Sense the Outside? Int J Mol Sci. 2017;18(6).

* A comprehensive review of lectins and lectin receptor-like kinases, summarizing the evolution of different classes of lectins and their domain architectures.

4. Reference 18. Dinh C, Farinholt T, Hirose S, Zhuchenko O, Kuspa A. Lectins modulate the microbiota of social amoebae. Science. 2018 Jul 27;361(6400):402-6.

** This paper shows that an amoeba secreted lectin alters grazing and killing of bacteria. It also allows for amoeba cells to harbor intracellular live bacteria following phagocytosis. Strikingly, this bacterial carriage leads to high rates of amoeba transformation, as plasmids from the bacteria are transferred to and expressed within the amoebae.

5. Reference 23. Gao Y, Wang W, Zhang T, Gong Z, Zhao H, Han G-Z. Out of Water: The Origin and Early Diversification of Plant R-Genes. Plant Physiol. 2018 Mar 21;pp.00185.2018.

** A thorough survey of the diversification of $R$-gene (resistance gene) proteins and domain architectures in Archaeplastida, including plant-type NLRs in numerous earlybranching lineages.

6. Reference 25. Urbach JM, Ausubel FM. The NBS-LRR architectures of plant R-proteins and metazoan NLRs evolved in independent events. Proc Natl Acad Sci. 2017 Jan 31;114(5):1063-8.

** A detailed study of the evolutionary history of plant and animal NLRs (nucleotidebinding domain, leucine-rich repeat superfamily), demonstrating that their domain architectures evolved at least twice independently.

7. Reference 26. Richter DJ, Fozouni P, Eisen MB, King N. Gene family innovation, conservation and loss on the animal stem lineage. Telford MJ, editor. eLife. 2018 May 31;7:e34226.

* Survey of transcriptomes across Choanoflagellatea, documenting a history of global gene gain and loss across Choanozoa. Includes discovery of kinase TLRs and assessment of TLR pathway conservation in animals and choanoflagellates.

8. Reference 54. Enard D, Cai L, Gwennap C, Petrov DA. Viruses are a dominant driver of protein adaptation in mammals. McVean G, editor. eLife. 2016 May 17;5:e12469.

* See reference 55, Shultz and Sackton (2019).

Reference 55. Shultz AJ, Sackton TB. Immune genes are hotspots of shared positive selection across birds and mammals. Landry CR, Tautz D, editors. eLife. 2019 Jan 8;8:e41815.

** Together with Enard et al (2016), this paper performed a genome-wide screen for genes under positive selection, finding that the strongest adaptation is in pathogeninteracting genes. The same gene families in birds and mammals are independently experiencing these selective pressures.

9. Reference 65. Dunn JD, Bosmani C, Barisch C, Raykov L, Lefrançois LH, Cardenal-Muñoz E, et al. Eat Prey, Live: Dictyostelium discoideum As a Model for Cell-Autonomous Defenses. Front Immunol. 2018;8:1906.

** Comprehensive review comparing and contrasting modes of bacterial antagonism present in mammalian phagocytes and Dictyostelium amoebae. 
10. Reference 70. Cepas V, López Y, Gabasa Y, Martins CB, Ferreira JD, Correia MJ, et al. Inhibition of Bacterial and Fungal Biofilm Formation by 675 Extracts from Microalgae and Cyanobacteria. Antibiotics. 2019 Jun 12;8(2):77.

* Detected antibacterial activity within extracts from cell cultures of over 200 diverse microalgal species representing more than 10 different eukaryotic groups (including Cercozoa, Chlorophyta, Cryptista, Euglenida, Haptista, Myzozoa, Ochrophyta and Rhodophyta).

11. Reference 77. Brennan JJ, Messerschmidt JL, Williams LM, Matthews BJ, Reynoso M, Gilmore TD. Sea anemone model has a single Toll-like receptor that can function in pathogen detection, NF-KB signal transduction, and development. Proc Natl Acad Sci. 2017 Nov 21;114(47):E1012231.
* Among the first studies to characterize Toll-like receptor function in an early-branching animal lineage, the cnidarian Nematostella vectensis, finding that key interactions with intracellular binding partners are conserved with bilaterian animals and that the TLR also functions in early embryonic development.

\section{References}

1. Knoll AH. Life on a Young Planet: the First Three Billion Years of Evolution on Earth. 2015. $296 \mathrm{p}$.

2. Whitman WB, Coleman DC, Wiebe WJ. Prokaryotes: The unseen majority. Proc Natl Acad Sci. 1998 Jun 9;95(12):6578-83.

3. Medzhitov R, Janeway CA. Innate Immunity: The Virtues of a Nonclonal System of Recognition. Cell. 1997 Oct;91(3):295-8.

4. Danilova N. The evolution of immune mechanisms. J Exp Zoolog B Mol Dev Evol. 2006 Nov 15;306B(6):496-520.

5. Adl SM, Bass D, Lane CE, Lukeš J, Schoch CL, Smirnov A, et al. Revisions to the Classification, Nomenclature, and Diversity of Eukaryotes. J Eukaryot Microbiol. 2019 Jan 1;66(1):4-119.

6. de Vargas C, Audic S, Henry N, Decelle J, Mahe F, Logares R, et al. Eukaryotic plankton diversity in the sunlit ocean. Science. 2015 May 22;348(6237):1261605-1261605.

7. Mahé F, de Vargas C, Bass D, Czech L, Stamatakis A, Lara E, et al. Parasites dominate hyperdiverse soil protist communities in Neotropical rainforests. Nat Ecol Evol. $2017 \mathrm{Mar}$ 20;1:0091.

8. Keeling PJ, Burki F, Wilcox HM, Allam B, Allen EE, Amaral-Zettler LA, et al. The Marine Microbial Eukaryote Transcriptome Sequencing Project (MMETSP): Illuminating the Functional Diversity of Eukaryotic Life in the Oceans through Transcriptome Sequencing. Roberts RG, editor. PLoS Biol. 2014 Jun 24;12(6):e1001889.

9. Monroe KM, McWhirter SM, Vance RE. Identification of Host Cytosolic Sensors and Bacterial Factors Regulating the Type I Interferon Response to Legionella pneumophila. Isberg RR, editor. PLoS Pathog. 2009 Nov 20;5(11):e1000665.

10. tenOever BR. The Evolution of Antiviral Defense Systems. Cell Host Microbe. 2016 Feb;19(2):142-9.

11. Zhao J-H, Guo H-S. Trans-kingdom RNA interactions drive the evolutionary arms race between hosts and pathogens. Curr Opin Genet Dev. 2019 Oct;58-59:62-9.

12. Shiner EK, Rumbaugh KP, Williams SC. Interkingdom signaling: Deciphering the language of acyl homoserine lactones. FEMS Microbiol Rev. 2005 Nov 1;29(5):935-47.

13. Amin SA, Parker MS, Armbrust EV. Interactions between Diatoms and Bacteria. Microbiol Mol Biol Rev. 2012 Sep 1;76(3):667-84.

14. Haldar K, Kamoun S, Hiller NL, Bhattacharje S, van Ooij C. Common infection strategies of 
pathogenic eukaryotes. Nat Rev Microbiol. 2006 Dec;4(12):922-31.

15. Bjorbækmo MFM, Evenstad A, Røsæg LL, Krabberød AK, Logares R. The planktonic protist interactome: where do we stand after a century of research? bioRxiv. 2019 May 2;587352.

16. Kilpatrick D. Animal lectins: a historical introduction and overview. Biochim Biophys Acta BBA - Gen Subj. 2002 Sep 19;1572(2-3):187-97.

17. Bellande K, Bono J-J, Savelli B, Jamet E, Canut H. Plant Lectins and Lectin Receptor-Like Kinases: How Do They Sense the Outside? Int J Mol Sci. 2017;18(6).

18. Dinh C, Farinholt T, Hirose S, Zhuchenko O, Kuspa A. Lectins modulate the microbiota of social amoebae. Science. 2018 Jul 27;361(6400):402-6.

19. Margolis SR, Wilson SC, Vance RE. Evolutionary Origins of cGAS-STING Signaling. Trends Immunol. 2017 Oct;38(10):733-43.

20. Whiteley AT, Eaglesham JB, de Oliveira Mann CC, Morehouse BR, Lowey B, Nieminen EA, et al. Bacterial cGAS-like enzymes synthesize diverse nucleotide signals. Nature. 2019 Mar;567(7747):194-9.

21. Ausubel FM. Are innate immune signaling pathways in plants and animals conserved? Nat Immunol. 2005 Oct;6(10):973-9.

22. Jacob F, Vernaldi S, Maekawa T. Evolution and Conservation of Plant NLR Functions. Front Immunol. 2013;4:297.

23. Gao Y, Wang W, Zhang T, Gong Z, Zhao H, Han G-Z. Out of Water: The Origin and Early Diversification of Plant R-Genes. Plant Physiol. 2018 Mar 21;pp.00185.2018.

24. Segonzac C, Zipfel C. Activation of plant pattern-recognition receptors by bacteria. Curr Opin Microbiol. 2011 Feb;14(1):54-61.

25. Urbach JM, Ausubel FM. The NBS-LRR architectures of plant R-proteins and metazoan NLRs evolved in independent events. Proc Natl Acad Sci. 2017 Jan 31;114(5):1063-8.

26. Richter DJ, Fozouni P, Eisen MB, King N. Gene family innovation, conservation and loss on the animal stem lineage. Telford MJ, editor. eLife. 2018 May 31;7:e34226.

27. Diévart A, Gilbert N, Droc G, Attard A, Gourgues M, Guiderdoni E, et al. Leucine-Rich repeat receptor kinases are sporadically distributed in eukaryotic genomes. BMC Evol Biol. 2011;11(1):367.

28. Jones JDG, Vance RE, Dangl JL. Intracellular innate immune surveillance devices in plants and animals. Science. 2016 Dec 2;354(6316):aaf6395-aaf6395.

29. Janeway CA, Medzhitov R. Innate Immune Recognition. Annu Rev Immunol. 2002 Apr;20(1):197-216.

30. Shalini S, Dorstyn L, Dawar S, Kumar S. Old, new and emerging functions of caspases. Cell Death Differ. 2015 Apr;22(4):526-39.

31. Walk A, Callahan J, Srisawangvong P, Leuschner J, Samaroo D, Cassilly D, et al. Lipopolysaccharide enhances bactericidal activity in Dictyostelium discoideum cells. Dev Comp Immunol. 2011 Aug;35(8):850-6.

32. Uehling J, Deveau A, Paoletti M. Do fungi have an innate immune response? An NLRbased comparison to plant and animal immune systems. Zipfel C, editor. PLOS Pathog. 2017 Oct 26;13(10):e1006578.

33. Kombrink A, Tayyrov A, Essig A, Stöckli M, Micheller S, Hintze J, et al. Induction of antibacterial proteins and peptides in the coprophilous mushroom Coprinopsis cinerea in response to bacteria. ISME J. 2019 Mar;13(3):588-602.

34. Zipfel C. Plant pattern-recognition receptors. Trends Immunol. 2014 Jul;35(7):345-51.

35. Duszenko M, Ginger ML, Brennand A, Gualdrón-López M, Colombo MI, Coombs GH, et al. Autophagy in protists. Autophagy. 2011 Oct 27;7(2):127-58.

36. de Duve C. The Lysosome Concept. In: de Reuck AVS, Cameron MP, editors. Novartis Foundation Symposia [Internet]. Chichester, UK: John Wiley \& Sons, Ltd; 1963. p. 1-35. Available from: https://dx.doi.org/10.1002/9780470715314.ch1

37. Gatica D, Lahiri V, Klionsky DJ. Cargo recognition and degradation by selective autophagy. 
Nat Cell Biol. 2018 Mar;20(3):233-42.

38. Cardenal-Muñoz E, Arafah S, López-Jiménez AT, Kicka S, Falaise A, Bach F, et al. Mycobacterium marinum antagonistically induces an autophagic response while repressing the autophagic flux in a TORC1- and ESX-1-dependent manner. Lewinsohn DM, editor. PLoS Pathog. 2017 May 17;13(4):e1006344.

39. Pizarro-Cerdá J, Cossart P. Bacterial Adhesion and Entry into Host Cells. Cell. 2006 Feb 24;124(4):715-27.

40. Weiss G, Schaible UE. Macrophage defense mechanisms against intracellular bacteria. Immunol Rev. 2015 Mar;264(1):182-203.

41. Monzingo AF, Marcotte EM, Hart PJ, Robertas JD. Chitinases, chitosanases, and lysozymes can be divided into procaryotic and eucaryotic families sharing a conserved core. Nat Struct Biol. 1996 Feb;3(2):133-40.

42. Wang G, Li X, Wang Z. APD3: the antimicrobial peptide database as a tool for research and education. Nucleic Acids Res. 2016 Feb 3;44(D1):D1087-93.

43. Núñez G, Sakamoto K, Soares MP. Innate Nutritional Immunity. J Immunol. 2018 Jul 1;201(1):11-8.

44. Verbon EH, Trapet PL, Stringlis IA, Kruijs S, Bakker PAHM, Pieterse CMJ. Iron and Immunity. Annu Rev Phytopathol. 2017 Aug 4;55(1):355-75.

45. Kubohara $Y$, Shiratsuchi $Y$, Ishigaki $H$, Takahashi K, Oshima $Y$, Kikuchi H. Antimicrobial Activities of Dictyostelium Differentiation-Inducing Factors and Their Derivatives. Biomolecules. 2019 Jun;9(5):163.

46. Qi J, Wang J, Gong Z, Zhou J-M. Apoplastic ROS signaling in plant immunity. Curr Opin Plant Biol. 2017 Aug;38:92-100.

47. Nguyen GT, Green ER, Mecsas J. Neutrophils to the ROScue: Mechanisms of NADPH Oxidase Activation and Bacterial Resistance. Front Cell Infect Microbiol. 2017 Aug 25;7:373.

48. Serrano I, Audran C, Rivas S. Chloroplasts at work during plant innate immunity. J Exp Bot. 2016 Jun;67(13):3845-54.

49. Sander LE, Garaude J. The mitochondrial respiratory chain: A metabolic rheostat of innate immune cell-mediated antibacterial responses. Mitochondrion. $2018 \mathrm{Jul} ; 41: 28-36$.

50. Jorgensen I, Rayamajhi M, Miao EA. Programmed cell death as a defence against infection. Nat Rev Immunol. 2017 Mar;17(3):151-64.

51. Liu X, Lieberman J. Chapter Three - A Mechanistic Understanding of Pyroptosis: The Fiery Death Triggered by Invasive Infection. In: Alt FW, editor. Advances in Immunology [Internet]. Academic Press; 2017. p. 81-117. Available from: http://www.sciencedirect.com/science/article/pii/S0065277617300184

52. Deponte M. Programmed cell death in protists. Biochim Biophys Acta BBA - Mol Cell Res. $2008 \mathrm{Jul} ; 1783(7): 1396-405$.

53. Shub DA. Bacterial Viruses: Bacterial altruism? Curr Biol. 1994 Jun 1;4(6):555-6.

54. Enard D, Cai L, Gwennap C, Petrov DA. Viruses are a dominant driver of protein adaptation in mammals. McVean G, editor. eLife. 2016 May 17;5:e12469.

55. Shultz AJ, Sackton TB. Immune genes are hotspots of shared positive selection across birds and mammals. Landry CR, Tautz D, editors. eLife. 2019 Jan 8;8:e41815.

56. Daugherty MD, Malik HS. Rules of Engagement: Molecular Insights from Host-Virus Arms Races. Annu Rev Genet. 2012;46(1):677-700.

57. Radivojac P, Clark WT, Oron TR, Schnoes AM, Wittkop T, Sokolov A, et al. A large-scale evaluation of computational protein function prediction. Nat Methods. 2013 Mar; 10(3):2217.

58. del Campo J, Sieracki ME, Molestina R, Keeling P, Massana R, Ruiz-Trillo I. The others: our biased perspective of eukaryotic genomes. Trends Ecol Evol. 2014 May 1;29(5):252-9.

59. Abida H, Ruchaud S, Rios L, Humeau A, Probert I, De Vargas C, et al. Bioprospecting Marine Plankton. Mar Drugs. 2013 Nov 14;11(11):4594-611. 
60. Waller RF, Cleves PA, Rubio-Brotons M, Woods A, Bender SJ, Edgcomb V, et al. Strength in numbers: Collaborative science for new experimental model systems. PLOS Biol. 2018 Jul 2;16(7):e2006333.

61. Levin TC, Greaney AJ, Wetzel L, King N. The rosetteless gene controls development in the choanoflagellate S. rosetta. Sánchez Alvarado A, editor. eLife. 2014 Oct 9;3:e04070.

62. Boamah DK, Zhou G, Ensminger AW, O'Connor TJ. From Many Hosts, One Accidental Pathogen: The Diverse Protozoan Hosts of Legionella. Front Cell Infect Microbiol [Internet]. 2017 [cited 2019 Aug 28];7. Available from: https://www.frontiersin.org/articles/10.3389/fcimb.2017.00477/full

63. Ramanan R, Kim B-H, Cho D-H, Oh H-M, Kim H-S. Algae-bacteria interactions: Evolution, ecology and emerging applications. Biotechnol Adv. 2016 Feb 2;34(1):14-29.

64. Seastone DJ, Zhang L, Buczynski G, Rebstein P, Weeks G, Spiegelman G, et al. The Small Mr Ras-like GTPase Rap1 and the Phospholipase C Pathway Act to Regulate Phagocytosis in Dictyostelium discoideum. Pfeffer SR, editor. Mol Biol Cell. 1999 Feb;10(2):393-406.

65. Dunn JD, Bosmani C, Barisch C, Raykov L, Lefrançois LH, Cardenal-Muñoz E, et al. Eat Prey, Live: Dictyostelium discoideum As a Model for Cell-Autonomous Defenses. Front Immunol. 2018;8:1906.

66. Mora C, Tittensor DP, Adl S, Simpson AGB, Worm B. How Many Species Are There on Earth and in the Ocean? Mace GM, editor. PLoS Biol. 2011 Aug 23;9(8):e1001127.

67. NCBI Resource Coordinators. Database resources of the National Center for Biotechnology Information. Nucleic Acids Res. 2016 Jan 4;44(D1):D7-19.

68. Falaise C, François C, Travers M-A, Morga B, Haure J, Tremblay R, et al. Antimicrobial Compounds from Eukaryotic Microalgae against Human Pathogens and Diseases in Aquaculture. Mar Drugs. 2016 Sep 2;14(9):159.

69. Shannon E, Abu-Ghannam N. Antibacterial Derivatives of Marine Algae: An Overview of Pharmacological Mechanisms and Applications. Mar Drugs. 2016 Apr 22;14(4):81.

70. Cepas V, López Y, Gabasa Y, Martins CB, Ferreira JD, Correia MJ, et al. Inhibition of Bacterial and Fungal Biofilm Formation by 675 Extracts from Microalgae and Cyanobacteria. Antibiotics. 2019 Jun 12;8(2):77.

71. Davison JR, Bewley CA. Antimicrobial Chrysophaentin Analogs Identified from Laboratory Cultures of the Marine Microalga Chrysophaeum taylorii. J Nat Prod. 2019 Jan 25;82(1):148-53.

72. Dyrka W, Lamacchia M, Durrens $P$, Kobe B, Daskalov A, Paoletti M, et al. Diversity and Variability of NOD-Like Receptors in Fungi. Genome Biol Evol. 2014 Dec;6(12):3137-58.

73. Jones D, Thomas C, Hammond-Kosack K, Balint-Kurti P, Jones J. Isolation of the tomato Cf-9 gene for resistance to Cladosporium fulvum by transposon tagging. Science. $1994 \mathrm{Nov}$ 4;266(5186):789-93.

74. Zou H, Henzel WJ, Liu X, Lutschg A, Wang X. Apaf-1, a Human Protein Homologous to C. elegans CED-4, Participates in Cytochrome c-Dependent Activation of Caspase-3. Cell. 1997 Aug;90(3):405-13.

75. Marron AO, Ratcliffe S, Wheeler GL, Goldstein RE, King N, Not F, et al. The Evolution of Silicon Transport in Eukaryotes. Mol Biol Evol. 2016 Dec;33(12):3226-48.

76. Jeandroz S, Wipf D, Stuehr DJ, Lamattina L, Melkonian M, Tian Z, et al. Occurrence, structure, and evolution of nitric oxide synthase-like proteins in the plant kingdom. Sci Signal. 2016 Mar 1;9(417):re2-re2.

77. Brennan JJ, Messerschmidt JL, Williams LM, Matthews BJ, Reynoso M, Gilmore TD. Sea anemone model has a single Toll-like receptor that can function in pathogen detection, NFKB signal transduction, and development. Proc Natl Acad Sci. 2017 Nov 21;114(47):E10122-31.

78. Brandt JP, Ringstad N. Toll-like Receptor Signaling Promotes Development and Function of Sensory Neurons Required for a C. elegans Pathogen-Avoidance Behavior. Curr Biol. 2015 
Aug;25(17):2228-37.

79. Antolín-Llovera M, Ried MK, Binder A, Parniske M. Receptor Kinase Signaling Pathways in Plant-Microbe Interactions. Annu Rev Phytopathol. 2012 Sep 8;50(1):451-73.

80. Kufer TA, Sansonetti PJ. NLR functions beyond pathogen recognition. Nat Immunol. 2011 Feb;12(2):121-8.

81. Wu X, Wu F-H, Wang X, Wang L, Siedow JN, Zhang W, et al. Molecular evolutionary and structural analysis of the cytosolic DNA sensor cGAS and STING. Nucleic Acids Res. 2014 Jul 29;42(13):8243-57.

82. Sharon N. Lectins. In: John Wiley \& Sons, Ltd, editor. eLS [Internet]. Chichester, UK: John Wiley \& Sons, Ltd; 2009 [cited 2019 Jun 27]. Available from: http://doi.wiley.com/10.1002/9780470015902.a0000708.pub2

83. Britzen-Laurent N, Herrmann C, Naschberger E, Croner RS, Stürzl M. Pathophysiological role of guanylate-binding proteins in gastrointestinal diseases. World J Gastroenterol. 2016;22(28):6434.

84. Maróti G, Kereszt A, Kondorosi É, Mergaert P. Natural roles of antimicrobial peptides in microbes, plants and animals. Res Microbiol. 2011 May;162(4):363-74.

85. Andreakis N, D'Aniello S, Albalat R, Patti FP, Garcia-Fernandez J, Procaccini G, et al. Evolution of the Nitric Oxide Synthase Family in Metazoans. Mol Biol Evol. 2011 Jan 1;28(1):163-79.

86. Kawahara B, Quinn MT, Lambeth JD. Molecular evolution of the reactive oxygen-generating NADPH oxidase (Nox/Duox) family of enzymes. BMC Evol Biol. 2007;7(1):109.

87. Egan S, Fernandes ND, Kumar V, Gardiner M, Thomas T. Bacterial pathogens, virulence mechanism and host defence in marine macroalgae: Bacterial pathogens of macroalgae. Environ Microbiol. 2014 Apr;16(4):925-38.

88. Geiszt M, Leto TL. The Nox Family of NAD(P)H Oxidases: Host Defense and Beyond. J Biol Chem. 2004 Dec 10;279(50):51715-8.

89. Wang Y-J, Wei X-Y, Jing X-Q, Chang Y-L, Hu C-H, Wang X, et al. The Fundamental Role of NOX Family Proteins in Plant Immunity and Their Regulation. Int J Mol Sci. 2016 Jul;17(6):805.

90. Nevo Y, Nelson N. The NRAMP family of metal-ion transporters. Biochim Biophys Acta BBA - Mol Cell Res. 2006 Jul;1763(7):609-20. 


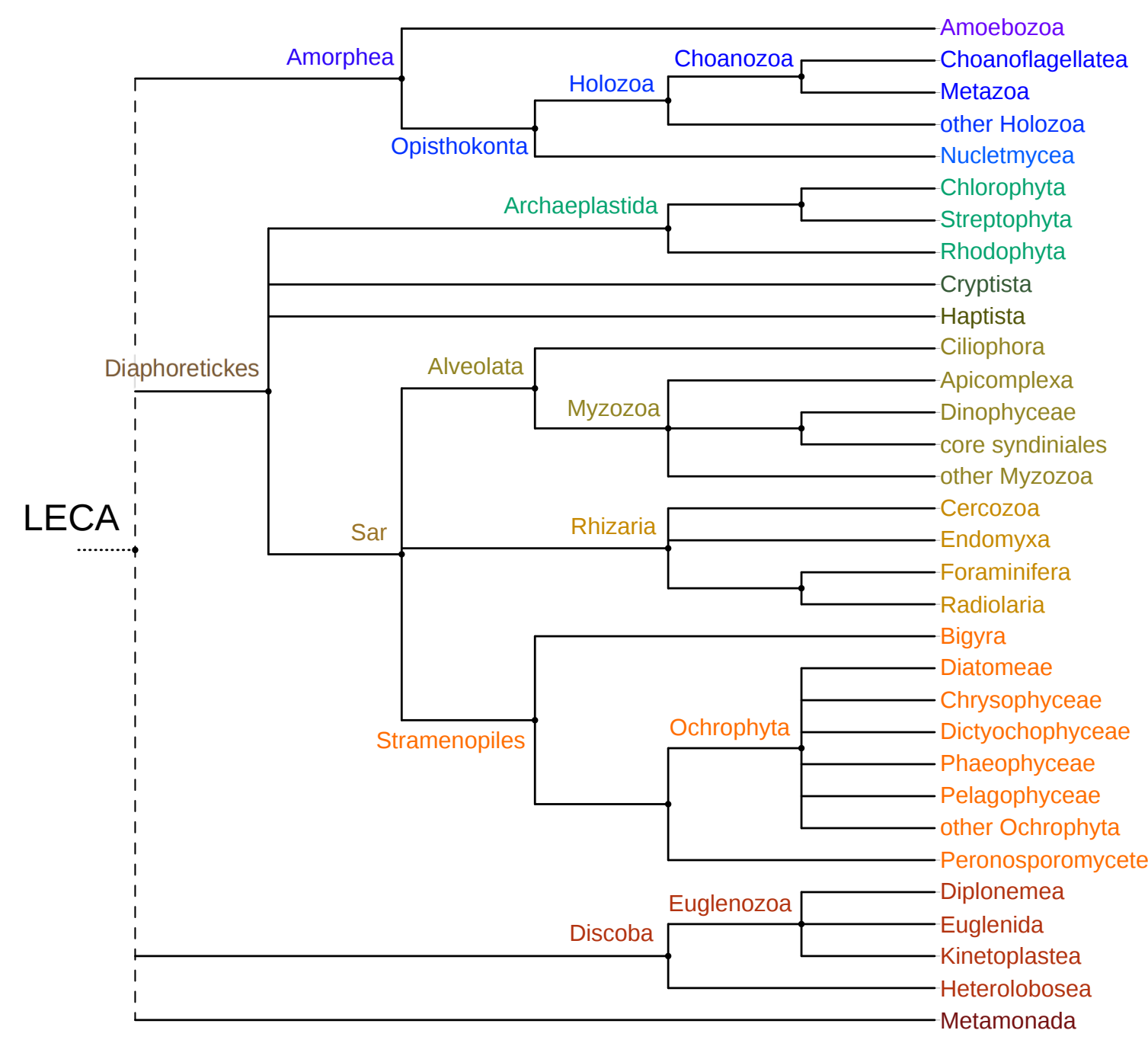

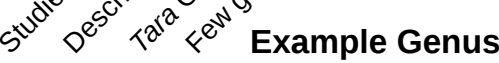

\ $\bigcirc 0$ Dictyostelium (cellular slime mold)

$\circ \quad 0 \quad$ Salpingoeca

$\uparrow \bigcirc$ Mus (mouse)

- 0 x Capsaspora

t 0 Saccharomyces (yeast)

is Chlamydomonas (green alga)

0 Arabidopsis (rockcress)

约 0 Porphyra (red alga)

出 0 Guillardia

出 0 Emiliania (coccolithophore)

虫 Tetrahymena (ciliate)

○ Plasmodium (malaria)

0

$\circ \mathrm{x}$ Perkinsus

幽 $\bigcirc \times$ Bigelowiella

- $O x$ Gromia

○ $\bigcirc$ Reticulomyxa

$\bigcirc \bigcirc \mathrm{X}$ Amphilonche

- $\mathrm{X}$ Cafeteria

s Thalassiosira (diatom)

药 $\bigcirc \times$ Paraphysomonas (golden alga)

- $\bigcirc \mathrm{x}$ Florenciella

↔ $\circ$ X Ectocarpus (brown alga)

㚎. $0 \mathrm{x}$ Pelagomonas

- 0 x Triparma

- $\quad$ Phytophthora (potato blight)

- X Diplonema

$\backsim \circ \circ X$ Euglena

- $\bigcirc$ Trypanosoma (sleeping sickness)

s $0 \circ \times$ Naegleria

$\bigcirc \quad$ x Giardia

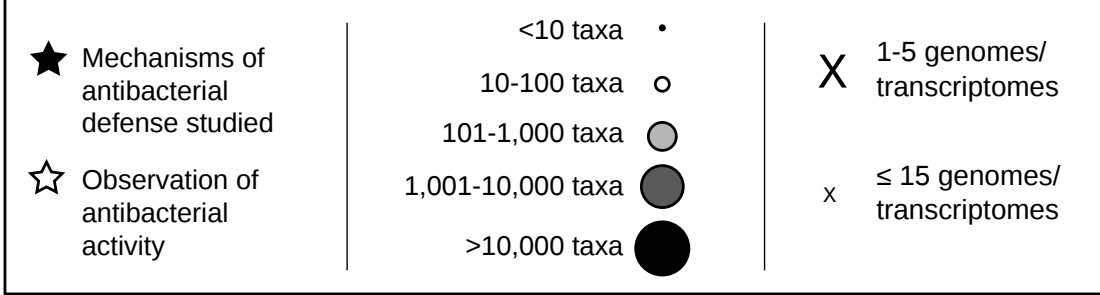


a

\begin{tabular}{ll}
$\begin{array}{c}\text { Domain architecture } \\
\text { in animals or plants }\end{array}$ & Example protein, Genus \\
\hline Animal TLRs: TIR, transmembrane, LRR & NP_991388 (TLR11), Mus \\
Plant receptor-like kinases: LRR/LysM, transmembrane, Pkinase
\end{tabular}

Amoebozoan TIR: RCC1, Ank, TIR

--

Animal NLRs: NACHT and LRR

$$
\text { NACHT LRR NP_001157214 (NLRX1), Mus }
$$

CARD NACHT NOD2_WH - NLRC4_HD2 LRR - XP_766317 (NOD1), Mus

PYRIN- NACHT NOD2_WH - NLRC4_HD2 LLRR-NP_766484 (NLRP4a), Mus
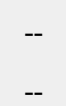

$--$

$--$

Plant NLRs: NB-ARC and LRR

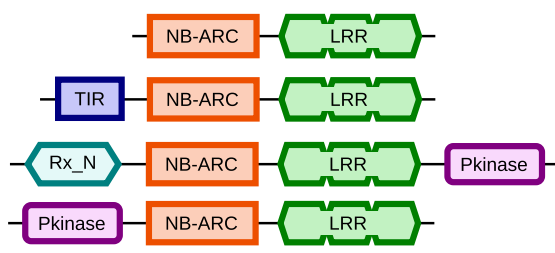

Fungal NLRs: central NACHT or NB-ARC

NP_001321385 (RFL1), Arabidopsis

NP_199338 (RPS4), Arabidopsis

XP_003576423, Brachypodium

XP_024379207, Physcomitrella

$--$ b
Domain architecture

in other eukaryotes

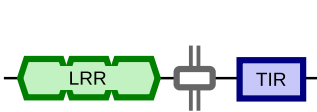
- C

\section{Example protein, Genus}

XP_004992000, Salpingoeca

CAMPEP_0206309248, Acanthoeca
Lineage(s) present outside animals/plants

\section{CLRP CAMPEP_0179057052, Pyrodinium All, except Apicomplexa \\ $-$}

Choanoflagellatea

Choanoflagellatea

RCC1 XP_636358 (tirA), Dictyostelium Amoebozoa

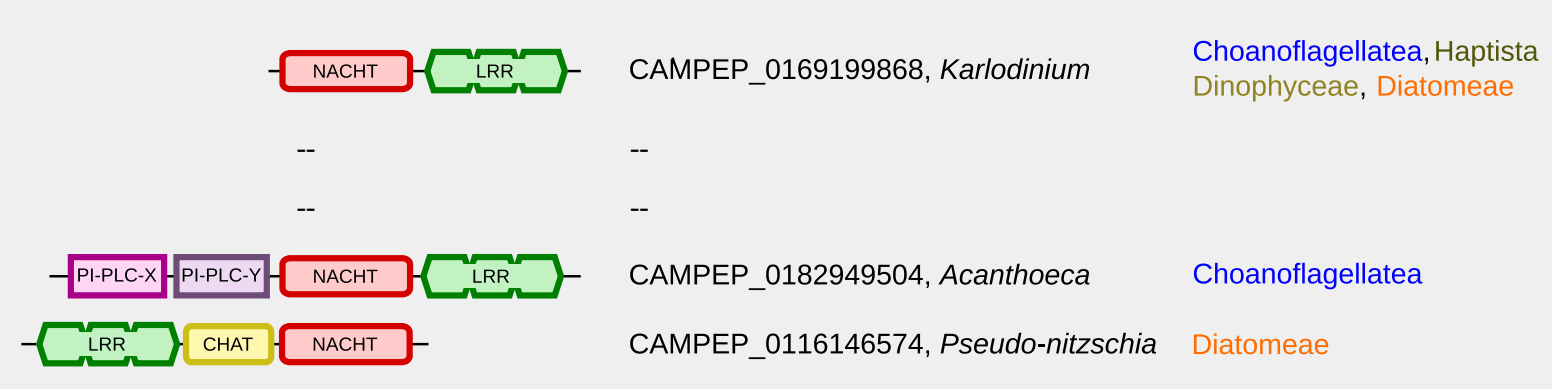

CHAT NB-ARC LRR

CAMPEP_0172974580, Phaeocystis

$-$

$--$

$-$

$\begin{array}{lll}\text { PNP_UDP NACHT } & \text { Nucletmycea } \\ \text { PNP_UDP_011325800, Fusarium } & \text { Nucletmycea }\end{array}$

XP_011325800, Fusarium

XP_001391272, Aspergillus

Haptista

--

CAN

XP

$-$ 


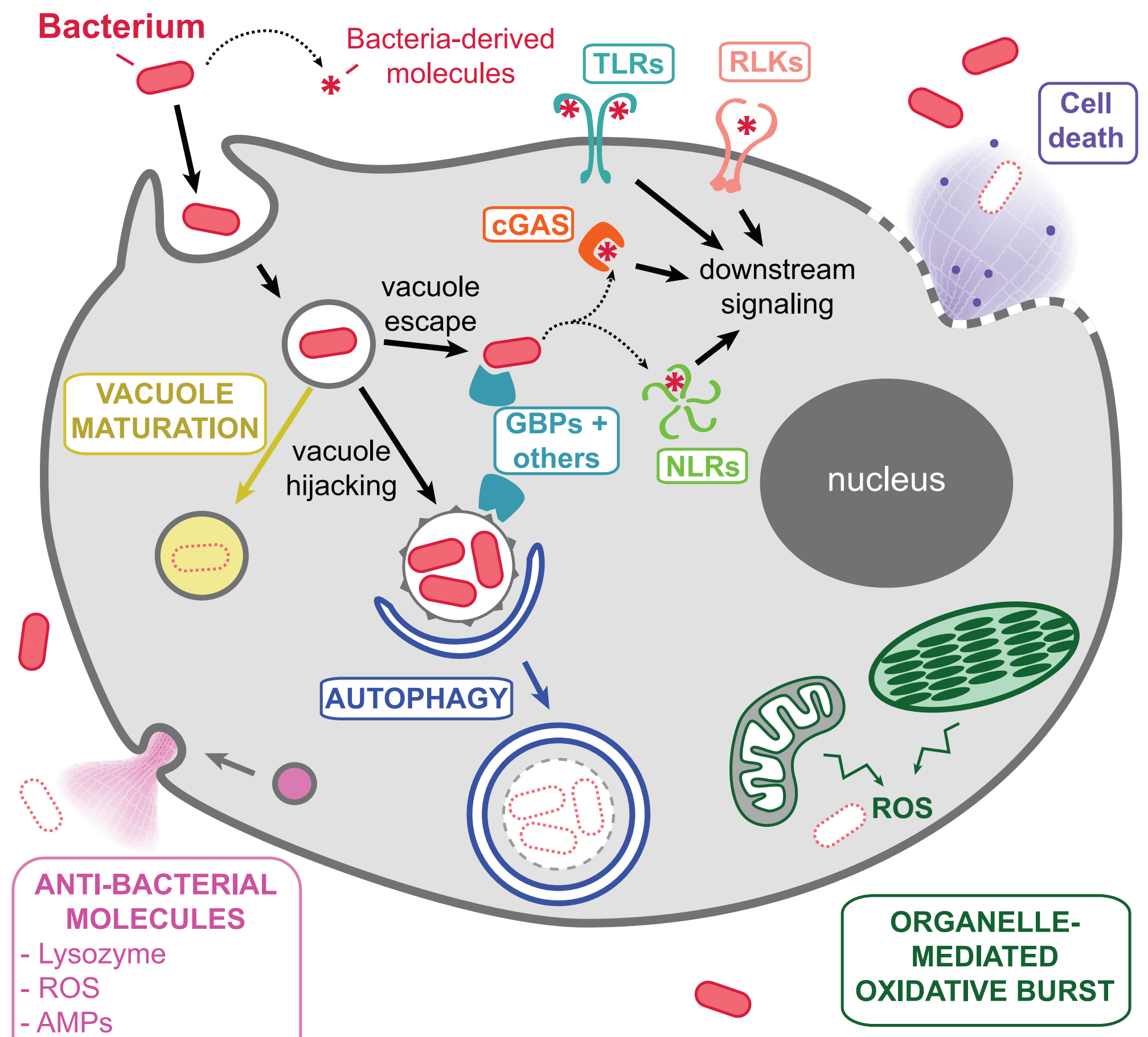

- Nutrient scavengers 